\title{
Construction of Character Education in Mandailing and Angkola Culture in North Sumatra Province
}

\author{
Rahmat Hidayat \\ Department of Islamic Education, Faculty of Islamic Studies, \\ Universitas Dharmawangsa, 20115, Medan, North Sumatra Province, Indonesia \\ * Corresponding Author: rahmathidayat@dharmawangsa.ac.id
}

\section{ARTICLE INFO}

Publication Info:

Research Article

How to cite:

Hidayat, R. (2020). Construction of Character Education in Mandailing and Angkola Culture in North Sumatra Province.

Society, 8(2), 611-627.

DOI: $10.33019 /$ society.v8i2.212

Copyright $\odot$ 2020. Owned by Author(s), published by Society

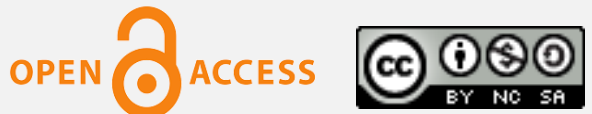

This is an open-access article.

License: Attribution-

NonCommercial-ShareAlike

(CC BY-NC-SA)

Received: July 20, 2020;

Accepted: November 1, 2020;

Published: December 30, 2020;

\section{ABSTRACT}

This research aims to describe the construction and character education model in Mandailing and Angkola tribes in North Sumatra Province. This research uses a qualitative method with a case study approach, a research method on individuals, groups, organizations, and specific institutions. Instruments or data collection tools used in this research are (1) observation; (2) in-depth interview; (3) document study. This research uses a method known as ethnography or participant observation. The result shows that Mandailing and Angkola tribes' characters building through 1) Socialization, 2) Enculturation, and 3) Internalization. Socialization including education, clarification, and motivation. Meanwhile, enculturation including imitation, habituation, and evaluation. Construction of education in Mandailing and Angkola tribes through habits, traditions, culture, and Islamic values. Character building in children is an effort to encourage self-awareness and concern for tradition, culture, and preserve local wisdom to sustain from generation to generation. Also, several efforts to preserve culture have been made by collaborating with schools, traditional and religious leaders to combine local wisdom and culture into schools' curriculum and extracurricular activities.
Keywords: Character Building; Character Education; Cultural Value; Indigenous Peoples; Local Wisdom

Copyright (C) 2020. Owned by Author(s), published by Society. This is an open-access article under the CC-BY-NC-SA license. 


\section{Introduction}

The community's current socio-cultural condition has shifted away from the religious and cultural values of the nation. Various social deviations have become the topic of daily news coverage by print and electronic media. It starts with alcoholism, drug abuse, student fighting, sexual behavior outside marriage, and various crimes (murder, mugging, robbery, corruption, and others). The study results show that globalization, mass media, and cross-cultural migration have a significant role in cultural change, from various phenomena of socio-cultural problems. It shows that, somehow, culture must be a consideration and concern despite differences (Demetrovics, 2012).

Research conducted by Manda \& Babo (2016) shows social deviations in the community, such as human trafficking, making the victims be commercial sex workers. Both from the victim and the perpetrator, the factors behind human trafficking are economic needs and other factors due to the environment and friends. The results also showed that deviant behavior also occurred in Pekalongan City schools, such as violent behavior, student fighting, and promiscuity. The factors that cause this deviation are thinking and emotional disturbance, lack of religious knowledge, broken family, and wrong education in the family and social environment (Yuniati et al., 2017).

Human life develops alongside the socio-cultural system, the economic system, and science and technology. Education is a planned effort to develop students' potential, so they have a system of thinking, values, morals, and beliefs inherited by their communities and develop the inheritance in an appropriate direction for present and future life. A great nation is a nation that has a strong character derived from the values unearthed from the culture of its people. Local wisdom values are not obstacles to progress in the global era, but it becomes an extraordinary transformational force in improving human resources' quality as a competitive capital and comparative advantage of a nation. Therefore, exploring local wisdom values is a strategic step to build the nation's character (Hidayat \& Rafida, 2019).

Traditions have good values. Research result conducted in Ciamis Regency, Indonesia, describes that local wisdom expressed in the Misalin tradition, such as religion, cooperation, art, history, and economy, is relevant for all time and is beneficial for future generations (Ratih, 2019). Furthermore, research result conducted in Maluku shows that the Niolilieta culture can make the people of the Wetang Island live more harmoniously, build good relationships, and socialize with the local environment (Ufie, 2016). The community's social solidarity is still well maintained even though there is a village expansion. Kinship, customs, and religion are considered collective assets that must be maintained that keeps the community strengthened and unchanged (Prayoga, 2017).

Hasanah et al. (2016) stated that Indonesian cultures play an important role in shaping Indonesian behavior with noble character. Local wisdom in Indonesia has one thing in common: fostering attitudes, behavior, and morality. It includes how to act and behave towards parents, guests, community, and nature in a more detailed way. In certain cultures, there are suggestions and prohibitions. This phenomenon is common among Indonesians. In other studies, culture can shape Mandailing community's character, which has cohesiveness, cooperation, work spirit, and kinship. Culture can shape and change character in Mandailing community. It shows that the dimension of Marsialap Ari culture is very central (Pulungan, 2017). A tribe with a rich culture such as Deli Malay tribe that combines tradition and Islamic teachings. The character values formed in Deli Malay tribe are religious, honest, tolerant, friendly, humble, and helpful. Education has built Deli Malay tribe's overall character value (Hidayat et al., 2020).

Copyright (C) 2020. Owned by Author(s), published by Society. This is an open-access article under the CC-BY-NC-SA license. 
Character education does not just understand the community as a place wherein character education should be present. It also becomes a pedagogical tool for people outside to become one to foster behavior and meaningful and useful values for the community itself. Therefore, any character education program must rely on the local community values as a cultural enrichment source implemented in schools' character education programs (Koesoema, 2011). According to Jeynes (2017), character education is related to high levels of outcomes. Character education is also related to integrity, love, compassion, and self-discipline. Overall, character education has a significant effect on students at school. The depiction of character education identifies as juvenility, moral values, and self-character. Character education has an essential role in constructing a child's self-identity (Pattaro, 2016). Other research results also suggest that it is necessary to effectively conduct training for teachers, change educational policies, and repackage the developing information to achieve educational progress. Character education is a knowledge intermediary (Walker et al., 2015).

According to Suyitno (2012), the educational process still focuses on cognitive achievement. Meanwhile, students' affective aspects, which are strong provisions for living in the community, have not been developed optimally. Therefore, character education and national culture is a necessity to be developed in schools. As agents of change, educational institutions need to strive earnestly for education based on national character and culture. National character and culture developed in schools must in line with local and regional characters and cultures. For that, character education and national culture need to be developed based on local wisdom.

Character development does not just happen. Habits, cultural conditions, and social attitudes are characteristic of every tribe in various parts of the world. The same thing can happen to the characters of Mandailing and Angkola tribes in North Sumatra Province. This research focuses on how the character building in the two tribes and how the educational models implement to build character and personality towards children based on acceptable norms and reflect education.

\section{Literature Review}

\subsection{Social Construction}

Polomo (2004) states that knowledge is defined as the certainty that phenomena are real and have unique characteristics in our daily lives. In reality, social reality does not stand alone without someone's presence, both inside and outside of that reality. Reality has meaning when the social reality is constructed and interpreted subjectively by other people to objectively establish this reality. Social construction is a statement of belief (a claim) and a point of view (a viewpoint) that the content of consciousness and how to deal with others taught by culture and society. Social construction is a point of view that all values, ideologies, and social institutions are human-made (Ngangi, 2011). According to Berger \& Luckmann (1990), daily life interprets as a reality by humans and has a subjective meaning for them as a coherent world. Society is a human product, and there is a dialectical process between society and humans. By their essence as creators of meaning, humans obtain life meaning from dialectical processes involving three processes: 1) externalization, 2) objectivation, and 3) internalization.

Basically, in humans, there is a relationship between the spirit and the body. The body is material, while the spirit is immaterial. The needs of human life include both of these elements. Material human activities aim to meet human bodies' needs (basic needs) such as food, drink, clothing, and shelter, often associated with aesthetic value needs. In addition to fulfilling material needs, humans also need to fulfill spiritual needs, in the form of safety and pleasure, 
which includes fulfilling the needs for love, affection, satisfaction, pleasure, and happiness. The fields that are a means of meeting spiritual needs, among others, are art or works of art.

However, in subsequent developments, artworks are sometimes no longer an expression of each individual's aesthetic value but rather a society's creative expression. Meeting the physical and spiritual needs requires institutions' existence, one of which is an educational institution. This institution's function is to mobilize environmental resources to accommodate education's needs based on the culture's framework. What is meant by education here is a process of cultural transfer, as models of knowledge, values, and beliefs. The transfer process is carried out by educators and accepted by students, related to culture used as a way of life.

The success of education measure by the extent to which the cultural transfer process is to remain able to maintain the continuity of culture from one generation to another. Besides, education also carries the mission of cultural renewal as a creative process. The results of such education in daily life manifested in various students' behavior patterns that enable them to play roles that are under cognitive, psychomotor, creative, and affective demands and allow them to have a new view that is unique to themselves and their environment (Koentjaraningrat, 2009).

\subsection{Character Education}

Lickona (1991) defines character as "A reliable inner disposition to respond to situations in a morally good way". Furthermore, Lickona added, "Character so conceived has three interrelated parts: moral knowing, moral feeling, and moral behavior". The noble character (good character), in Lickona's view, includes knowledge about goodness (moral knowing), then raises commitment (intention) towards goodness (moral feeling), and finally actually does goodness (moral behavior). In other words, a character refers to a series of knowledge (cognitive), attitudes, and motivations, as well as behaviors and skills.

Character education is plus moral education, including knowledge (cognitive), emotion, and action aspects. Without these three aspects, character education will not be effective, and its implementation must be carried out systematically and continuously and be able to differentiate from one another. With character education, a child will become emotionally quotient. It is consistent with the opinion of Goleman (2007), which stated that a person's success in society, $80 \%$ is influenced by Emotional Quotient (EQ) and $20 \%$ by Intelligence Quotient (IQ)". Character education must be a national movement that makes schools (educational institutions) an agent to build students' character through learning and modeling. Through character education, schools must bring students to have noble character values such as respect and care for others, responsibility, honesty, integrity, and discipline.

On the other hand, character education must also keep students away from despicable and prohibited attitudes and behaviors. Character education not only teaches what is right and what is wrong to children, but more than that, character education instills habits (habituation) about the good so that students understand, can feel, and want to do good. Thus, character education carries the same mission as moral education or moral education. Asserts that character education is a deliberate effort to help someone understand, maintain, and behave under noble characters' values. Schools can develop and integrate various character values in learning. However, integrating all of these values is a heavy task. Therefore, it is necessary to choose prioritized specific values for integrating into students. Character education aims to build a strong, competitive, noble, moral, tolerant, cooperative, patriotic-spirited, dynamic-developing, science-and-technology-oriented nation, all of which are inspired by faith and piety to God Almighty based on Pancasila (Frye, 2002). 


\subsection{Character Building Process}

Asmani (2012) states that character developed through the stages of knowing, acting, and habits. Thus, three components of good character are needed: moral knowing, emotional reinforcement, and moral action. Dimensions belonging to moral knowing to fill the cognitive area are moral awareness, knowing moral values, perspective-taking, moral reasoning, decision-making, and self-knowledge.

According to Ulwan (2013), there are five methods in educating children in the family to have good morals, namely exemplary, habits, advice, giving attention, and punishment. According to An-Nahlawi (1995), a family can do moral education for children through dialogue, stories, parables, models, practices, 'ibrah dan mau'idzah, targhib, and tarhib. According to Siswoyo (2005), early childhood moral education through as follows 1) indoctrination, 2) defining values, 3) exemplary, and 4) behavior habituation. On the other hand, according to Hasanah (2012), there are several steps in character education in Islam, including teaching, habituation, modeling, motivating, and enforcing rules.

\section{Research Methodology}

This research uses a method known as ethnography or participant observation. This method is also called the naturalistic qualitative method, aims to examine the ongoing cultural and social systems process in Mandailing and Angkola tribes in North Sumatra Province. This research focuses on the developed values in Mandailing and Angkola tribes in North Sumatra Province. These character values building process makes Mandailing and Angkola tribes' character different from other communities or tribes in North Sumatra Province. This research collects data repeatedly to the research location by recording data and information and then subsequently analyzing it. Data and information were collected, grouped, and analyzed. This research uses a qualitative method with a case study approach to research individuals, groups, organizations, and certain institutions (Sugiyono, 2016). Instruments or data collection tools used in this research are (1) observation; (2) in-depth interview; (3) document study. The data obtained were then analyzed using qualitative data analysis consisting of: (a) data reduction, (b) data presentation and, (c) conclusions, where the process took place circularly during the research. In the initial stages of data collection, the research's focus is still general and not yet apparent, while observation is still general and comprehensive. After the focus becomes apparent, this research uses more structured observations to get more specific data.

\section{Results and Discussion}

\subsection{Construction of Character Education in Mandailing and Angkola Tribes in North Sumatra Province}

Cultural values are values inherent in society that are useful for regulating harmony and balance in life. As a non-native tribe community in Medan city, Mandailing and Angkola tribes must demonstrate their cultural existence. It is undoubtedly a first step in maintaining noble values from generation to generation, not eroded by time and space. There must be many steps taken by Mandailing and Angkola tribes in Medan City to internalize these values for generations. The integration of existing cultural values in Mandailing and Angkola tribes to the children through family, school, and community education. At the family level, these values are introduced through education by parents in their daily lives. It starts with good language education. Then proceed with cultural values implementation in their daily lives. Parents become the first teacher for their children to transform existing cultural values. These values implement through advice (Sipaingot) and an excellent exemplary from parents. There are 
several stages in Islamic character education construction in Mandailing and Angkola tribes in Medan City: 1) Socialization, 2) Enculturation, and 3) Internalization.

\subsubsection{Socialization}

According to Soekanto (2012), socialization is when new community members learn their new community's norms and values. The socialization of Mandailing and Angkola cultural values begins from the family environment. Father and mother introduced the region's culture to their children, such as good behavior, speaking politely, and respecting others. The values instilled in the family then continued in the child's life at the educational institution. All school stakeholders are responsible for socializing cultural values to their students.

On the other hand, indigenous peoples' role also participated in socializing Mandailing and Angkola cultural values. Dalihan $\mathrm{Na}$ Tolu philosophy becomes a bond. It is a family bond and makes a significant contribution to the socialization of cultural values. Mandailing and Angkola cultural values socialize through traditional ceremonies: marriage, death, and ceremonial traditions. They are very active in managing social life through Islamic education, both formally through schools or madrassas (pesantren) and informal/non-formal education through teaching, lectures, social-religious activities, mass organizations activities, and practical politics. Generally, the Islamic teachings developed by charismatic scholars rely on figh (sharia), where the teachings filter out many social norms (traditions) in society. There are several steps taken by Mandailing and Angkola tribes in the socialization process, including:

1) Education

The educational process that has been carried out by Mandailing and Angkola communities in character building, including (1) introduction, teaching, and preservation of cultural values through families; (2) teaching, instill, and continuing and developing the family's cultural values through schools/madrasas; and (3) introduction, teaching, and instill of cultural values in the community through various traditional events.

2) Clarification.

In this approach, parents do not directly convey to children about right and wrong, good and bad, but parents allow children to express values in their way. Parents invite children to express why this action is right or wrong and discuss moral issues that develop. Giving positive feedback and reinforcement in verbal, written, gestured, or attitude to children is a character-building step. With this feedback, the child will know which values are compatible with religion and culture and are contrary to religious and cultural values.

3) Motivation

Motivation aims to make a motivated person obey or carry out what is motivated. Besides being given to individuals, individuals can also motivate groups, between groups to groups, and groups to individuals. Parents, teachers, and community leaders should be the pioneers in motivating children to become the next generation who have good character. Encouragement from various parties to children to behave well will undoubtedly affect the child's character development.

\subsubsection{Enculturation}

Koentjaraningrat (2009) states that enculturation is the process of studying and adjusting the minds and attitudes of individuals to the system of norms, traditions, and regulations in their culture. The process of enculturation of Mandailing and Angkola's cultural values also 
starts with family members. Father and mother accustom their children to speak regional languages to preserve the local language. This condition is undoubtedly essential to be carried out by Mandailing and Angkola tribes because the primary language in North Sumatra is Indonesian as an introduction rather than regional languages. So the local language is only used in families, fellow Mandailing and Angkola communities, and traditional ceremonies. On the other hand, the family also a place to integrate cultural values through moral habituation and rule enforcement.

Furthermore, educational institutions are also crucial in the process of enculturating these values. Cultural values will run well if the school stakeholders provide good examples, and students will imitate these values. Then habituation of something with good values must continue to be repeated and accustomed to becoming a culture. No less important is the school also enforces the rules that students must obey to survive in their lives in the broader community.

On the other hand, Dalihan Na Tolu's ties have a massive role in upholding the cultural values of Mandailing and Angkola. As a kinship system, Dalihan Na Tolu is used as a guideline for communicating (speaking), acting, and resolving social problems. At the same time, Islam as a religion adopted by South Tapanuli people also became the norm for life. Although both systems are the way of life, their use and practice differ from one community to another. Mandailing tribe is laxer towards traditional values than Angkola tribe, who are relatively obedient to traditional values. Thus, there will be interaction and interdependence between tradition and Islam, whether realized, intentional, or not in the community's life.

The research results by Febriansyah (2017) stated that the character values embodied in the tradition, culture, and religious concepts in the Sundanese Wiwitan community are religion, responsibility, love for the country, tolerance, social and environmental care. Implementation of character education through families, communities, and traditions in the Sundanese Wiwitan Cigugur community. The character values obtained following the community's traditions and the socio-cultural conditions of the community itself. Saihu \& Mailana (2019) stated the relevance of behavioristic education theory to local wisdom in Hindu and Muslim communities' character building in Jembrana to become humanist, pluralist, and tolerant. The relevance of local wisdom to national character development due to the value of local wisdom is not an obstacle in the globalization era. However, it is a significant force in building the nation's character.

There are several steps practiced by Mandailing and Angkola tribes in the enculturation process, including:

1) Imitation (Imitate)

Imitation is the action of using someone or something as a model, including their parents. When children learn to imitate, children's knowledge and social interaction will develop rapidly. Example: children imitate the habits of their parents eating with a spoon and fork. Speaking by their parents' talking style, how to dress, hairstyle, behave, and others. Therefore, in this imitation process, parents are expected to provide examples for their children to develop appropriately. Parents are the primary model (role model) for children. Father and mother are two people who play a role in parenting since the child is born. The way when parents are angry or when showing love, all children will imitate and learn it. If parents are accustomed to using harsh words or verbal abuse when upset with others, children will also learn it. So, when a child is upset with their friend, the child will do the same thing. Conversely, if parents teach to love each other, respect each other, respect guests, respect parents and siblings. Children will also imitate it. Children will show respect and be polite to everyone. Parents can develop the

Copyright ( $(2020$. Owned by Author(s), published by Society. This is an open-access article under the CC-BY-NC-SA license. https://doi.org/10.33019/society.v8i2.212 
character of children by giving good habituation. Habituation is a starting and fundamental way in character formation to bring positive reflexes for children to behave. Habit is crucial for character building and also for changing character.

On the other hand, the teacher and the community's role models must support parents' existence as the primary model (role model). Parents, teachers, and the community must set an example for students, ranging from their thoughts, speech, behavior, even their clothes; all of it will be a medium for children to imitate. In daily activities, children observe and find various values that develop in the community. If the values do not match the values taught at home or school, it is conceivable that the child will experience continuous intellectual confusion. It is regrettable if the child is finally more interested and chooses those values rather than the values instilled at school or home. Hence, the role of parents and school becomes vital. Therefore, besides having a strong character, parents and teachers must also be broad-minded. Exemplary is the principal in education because, without exemplary, the process of education is like a body without spirit.

Research by Fitriyani et al. (2015) stated that the effort of instilling and developing cultural inheritance in Sundanese families through 1) internalization, 2) socialization, and 3) enculturation, manifested in the use of Sundanese as a communication tool. Also, in the daily behavior of family members and sociological models that can be applied to develop Sundanese cultural values in the middle of cultural globalization. Another case study in East Kalimantan on the imitation of external culture produced positive values, namely the imitation of hip hop culture (rapper, hip hop dancer) as a form of work in achievements (Pradana, 2016).

\section{2) Habituation}

The success of character education also depends on the continuity of the child's behavior. It means that the goal of character education will never achieve if only done at one time. Character values instilled in children must always continue through the child's daily behavior habituation. For example, pray before eating, wash hands before eating, return the toy to its place, and others. If one day, the child does not do this, then the child should be given a warning.

On the other hand, Asyarafah (2011) explains a behavior building into habituation; at least, it must go through two stages: Mujahadah and Riyadhoh. First, Mujahadah, good behavior becomes a habit is not easy because it requires a long struggle and not enough with the intention alone. It needs a foundation of faith and the process of mobilizing the faith in the soul and being ready to resist the pressures of lust and Satan temptations. Therefore a hard struggle is needed, so this step is called Mujahadah. Second, Riyadhoh is repeating a behavior until it becomes a fixed and embedded habit in the soul to find soul satisfaction. Repetition of behavior continuously is a primary stage in habit building in general. Therefore, repetition of behavior in a certain way makes the behavior embedded in the soul. The soul no longer finds difficulties when it starts undergoing the initial stages of habit formation. Families need to create a friendly relationship. Children who have a harmonious relationship with parents and family have the ability and confidence to establish relationships with others.

Conversely, children who have problems with their core families usually fail to foster social relationships with others. Friendly and positive social interactions between parents and children will provide a pleasant understanding of social interactions. Even parents can train their children to participate in social activities in their neighborhood. It will foster a child's confidence to play a role in the environment.

Likewise, character education in schools/madrasas requires habituation in students

Copyright ( $(2020$. Owned by Author(s), published by Society. This is an open-access article under the CC-BY-NC-SA license. 
themselves. Through habituation or school culture, such as shaking hands, saying hello, praying sunnah Dhuha, is an activity carried out in the school environment that instills character values with necessary concepts. Norm must be taught/trained as reference behavior. In the context of Islamic education, the norm referred to is the Quran and Hadith. When commands in the Quran stated that humans must be honest and fair, the teacher teachings those commands and then systematically trains examples of honest and fair behavior to the students. For example, during an exam, some students cheat on each other in answering questions. The teacher punishes by disqualifying the exam results. It is an example of the teacher when treating their students fairly. Moreover, if there is a similar case that repeats, the teacher must consistently give the same punishment as the first while occasionally warning that it will be against religion (sinful). If the two methods are combined, it will form a combined/dialectical/deductive-inductive moral education method.

In practice, teachers often use both methods alternately or together by each school's situations and conditions and depend on the case. Research conducted by Emilda (2018) states that the Cireundeu traditional village community's cultural conditions, such as using cassava as a staple food and organizing the traditional Suraan ceremony, are held full month. The character values contained in cultural habituation are the value of tolerance, the value of cooperation, the value of resilience, the value of the economy, and the value of cultural awareness.

Andiarini et al. (2018) stated that the habituation at SMPN 1 Wlingi Blitar starts from planning, implementation, school members, supervisors, and implementers' roles could improve the institution's quality of character education. Habituation by Mandailing and Angkola tribes can foster character by involving indigenous peoples, families, and schools that are still adjusted to their local wisdom to maintain cultural preservation.

\section{3) Evaluation}

Evaluation is a process to provide information about the achievement of a specific activity, the difference in achievement with a certain standard, and the expectations' benefits. In the evaluation process, there are two things done by parents, teachers, and the community, namely giving rewards to children/community members who have good character and giving punishment to children/community members who have bad character. There are two types of reinforcement: positive reinforcement in the form of reward and negative reinforcement in the form of punishment. The reward is to give praise, give gifts, and things that can make students feel valued and motivated. The punishment is like to blame and makes students feel fallen in their self-confidence. Therefore the implementation of reward and punishment in education is significant and must be considered with its implementation, so there is no mistake in implement it.

\subsubsection{Internalization}

Internalization is the process of appreciation. The process of mastery in-depth takes places through counseling, training, upgrading, or specific other conditioning. Thus internalization is the process of introducing values to someone who will shape their mindset in seeing the meaning of the reality of experience. These values can be from various aspects of religion, culture, social norms, and others. This value's meaning colors the meaning and attitude of humans towards themselves, the environment, and reality. The internalization process is not only monotonous from the family but also the environment. The intended environment is the social environment. Unconsciously, various community leaders have been

Copyright ( $(2020$. Owned by Author(s), published by Society. This is an open-access article under the CC-BY-NC-SA license. https://doi.org/10.33019/society.v8i2.212 
influenced, such as teachers, religious teachers, and traditional leaders. The internalization process is personal. This process through self-development by learning from others, parents, teachers, and instructors in certain situations. Thus various cultural values that carry Islamic character in Mandailing and Angkola communities in the Province of North Sumatra come from families, schools, and indigenous peoples internalized into Mandailing and Angkola communities, thus forming character. This character distinguishes Mandailing and Angkola communities from other North Sumatra Province communities or other Indonesian communities.

\subsection{Character Shapes of Mandailing and Angkola Tribes in North Sumatra Province}

There are several shapes of Islamic character in Mandailing and Angkola communities in Medan City, as follows:

\subsubsection{Religious}

Religious values encourage someone to behave and act by the teachings of religion. Religious values significantly affect humans in behaving and acting. Someone has an excellent religious value if their behavior and attitude are good. Religion is a motivator for humans in building faith in God so that humans can always do well and always remember their God's greatness and have increased confidence in their God. Religiousness is related to oneself; the level of a religious person is different; religion has a perfect relationship between humans and God. These religious values aim to educate and encourage people to walk in the path of God, make people do well, and increase faith only in God. Mandailing and Angkola tribes are known as religious communities manifested from religious values' appreciation and practice in their daily lives.

On the other hand, evidence of Mandailing people's harmony marked by praising God. In traditional ceremonies, religion gives influences the course of the ceremony. The results of research by Siregar (2020) stated that an Islamic religious ritual and local traditional values in Mandailing and Angkola communities consist of Marpangir and Mangan Fajar. Marpangir (fragrant bath) is the tradition of the grave pilgrimage, carried out before Ramadan. Mangan Fajar carried out before performing the Eid prayers.

\subsubsection{Independent}

Independence is an individual's internal strength obtained through the individuation process: realizing selfhood and towards perfection. Asrori \& Ali (2011) stated that the self is the core of personality and is the central point that harmonizes and coordinates all aspects of personality. Then independence is a condition of someone who can stand alone who grows and develop because of discipline and commitment to determine themselves expressed in actions and behaviors. Mandailing and Angkola communities are known as independent communities due to their perseverance, efforts, and hard work, not because of the solitary group struggle as compactness seen in Toba Batak tribe.

\subsubsection{Wander}

The characteristic of Mandailing and Angkola people who like to wander is a manifestation of the values embedded in their culture: Hasangopan, Hamoraan, and Hamajuon. If someone studies or migrates to other areas to get a decent job, they will succeed and return to their hometown by bringing something new to their hometown. That is called progress, something achieved from other people's areas. This cultural value is powerful to encourage Mandailing and Angkola people to migrate throughout the country. Progress is gained from 
education and wanders to improve the standard of living physically and mentally. Of course, having qualified knowledge will impact the glory, authority, charisma, and power to achieve glory and property wealth (Hasangopan and Hamoraan). Mandailing people who like to migrate causes them to spread throughout Indonesia with various professions such as soldiers, advocates, business people, bureaucrats, economists, teachers, lecturers, and others. On the other hand, there are many among Mandailing people who migrate abroad, such as Malaysia, Saudi Arabia, the Netherlands, and others.

\subsubsection{Critical}

A critical attitude is beginning with critical thinking. Critical thinking is a mental process for analyzing or evaluating information, such as observations, experiences, common sense, or communication. Mandailing and Angkola communities are critical. Tapis in Mandailing means all behavior and people's words are listened to and filtered so that caution arises in doing and acting. It makes Mandailing and Angkola people like to be forthright and criticize the mistakes made by others. Critical is sensitivity, care, response to something, either positive or negative responses. This attitude is not to bring down or embarrass others, but this critical attitude is the attention and desire to get and build something ideally. By having a critical attitude, they need to be a person with a particular type who always has idealism, social sensitivity and concern, and the courage to express the truth about implementing appropriate regulation.

\subsubsection{Dare to Uphold the Truth}

Dare means have determination and self-confidence in facing danger, difficulties, and others. Thus, brave here is brave in a positive way. Opponents of the Syaja'ah characteristic are Jubun or Jabanah (cowardly). The brave are those who dare to defend the truth at any risk and are afraid to do what is not right. Conversely, timid are people who are afraid to defend the truth. Their jargon "Brave because right and fear because wrong". The character seen from the Mandiling and Angkola people is the courage to uphold the truth marked by the philosophy of Mandailing and Angkola people. The truth must be maintained, whatever the consequences. It causes Mandailing and Angkola people to dare to uphold the truth and dare to take risks that befall them in the future even though they are across the area. If there is something contrary to religious and cultural values, the people of Mandailing and Angkola become the front line in urging to these values without fear of accepting negative consequences in the future. Courage based on truth, carried out with full consideration and calculation to expect the pleasure of God. The philosophy of Mandailing and Angkola states, "Martaon Di Halidangan Jaru Pe Ontangan Ni Tolonan Nangkan Magotap" (persist in the truth even though the challenge is death). The main principle emphasized here is the willingness to sacrifice lives to defend the truth in the openness principle by the expressions that describe the following despicable attitude, "Mangkatai Pabalik-Balik Dingding Tartuas Eda Pantangan" (speaking about someone from behind a wall can cause slander). This philosophy makes the people of Mandailing and Angkola become people who like to be open in expressing opinions, even though others can hate the adverse effects.

\subsubsection{Great Sense of Shame (Parsulaha)}

The word shame means feeling very bad for doing something that is not good (not right, different from the habit, have disabilities or deficiencies). Mandailing and Angkola communities have a great sense of shame (Parsulaha). It has good and bad impacts. The characteristic of this Parsulaha has to do with the nature of caution to act and behave because

Copyright ( $(2020$. Owned by Author(s), published by Society. This is an open-access article under the CC-BY-NC-SA license.

https://doi.org/10.33019/society.v8i2.212

621 
their actions may be disturbing others or not pleasing others' hearts. However, from the negative side, it can cause obstacles for Mandailing people to forward. This great shame (Parsulaha) has been formed by Mandailing and Angkola tribes' families since childhood. Parents' advice is shown by asking their children not to beg for others even though their own close family. This attitude causes Mandailing people to have a high reluctance to ask for help from others unless the assistance itself comes not from accidental requests.

On the other hand, the people of Mandailing and Angkola always protect themselves from actions that tarnish family honor, such as adultery and sexual harassment. Adultery is an obligation that must be avoided by all parties in indigenous communities because this can be a big disgrace to the family. Among the expressions conveyed to children not to give disgrace to the family, "Na Tola Mardalan Halaklai Dohot Adaboru Na So Samarga" (forbidden to walk together between men and women of different clans). Furthermore, "Na Tola Mardua, Halak $\mathrm{Na}$ Marlainan Jenis Na So Samarga Di Na Sopi Dohot Di Na Holip" (forbidden to people of different sexes, different clans, in quiet and hidden place).

\subsubsection{Adaptable}

Self-adjustment is a process that includes mental and behavioral responses that individuals struggle to be able to face internal needs, failures, frustrations, conflicts, successful, and to produce quality harmony between the demands of the individual and the demands of the outside world or the environment in which individuals are on. So it can be concluded that a person is said to adjust well if they can foster good relationships between them and others. However, not all individuals can adjust themselves well. The habit of wandering makes Mandailing and Angkola people often meet with other cultures across the area. Mandailing and Angkola communities' uniqueness is that they are easily adaptable to the local cultural values where they migrate. Mandailing and Angkola communities will implement these cultural values if not clash with their culture and religion. For example, Mandailing and Angkola communities will use the language of other tribes when meeting one of them. Like using Betawi language when in Jakarta for an extended period, using Javanese when they migrate to Java, Sundanese if they are in West Java, and so forth. Many people, Mandailing and Angkola, are fluent in Betawi, Javanese, Sundanese, Malay, Batak, and so forth.

On the other hand, Mandailing and Angkola communities also adopted many other cultures in their lives. For example, the tradition of Tepung Segar and Bunga Bale in weddings and other traditional events. Both of these cultures are Melayu people's culture. However, it is not uncommon for us to see the tradition (Tepung Segar tradition) when they leave and return to perform their Hajj pilgrimage in Medan City and surrounding areas. Likewise, with the bale flower, Mandailing and Angkola communities no longer use the artwork according to the custom culture of Mandailing and Angkola but instead use the bale flowers as the accessories of visualization. Cultural mixing in an event is presently considered normal for Mandailing and Angkola communities. The friendly character of Mandailing and Angkola communities makes them quickly accepted across areas. Mandailing and Angkola communities much avoid themselves from cultural conflicts with the local communities where they migrate.

\subsubsection{High Sense of Kinship}

Mandailing community kinship's core value mainly relies upon Dalihan Na Tolu's implementation. This kinship relationship manifests in greetings, either because of blood ties and marital ties instilled in Mandailing and Angkola communities from an early age in the family. On the other hand, in family and community life, kinship has also been cultivated 
through the bond of love. Dalihan Na Tolu's existence has a huge role in creating an atmosphere of life that is quite good, conducive, mutual respect, and respect for others. The value of kinship felt when Mandailing and Angkola communities wander. They work hand in hand in the face of life.

Mandailing community kinship's core value mainly relies upon Dalihan Na Tolu's implementation. This kinship relationship manifests in greetings, either because of blood ties and marital ties instilled in Mandailing and Angkola communities from an early age in the family. On the other hand, in family and community life, kinship has also been cultivated through the bond of love. Dalihan $\mathrm{Na}$ Tolu's existence has a huge role in creating an atmosphere of life that is quite good, conducive, mutual respect, and respect for others. The value of kinship felt when Mandailing and Angkola communities wander. They work hand in hand in the face of life.

One way to establish kinship in Mandailing and Angkola communities in overseas lands is to establish various overseas organizations. There are associations based on Huta (autonomous settlement unit) and clan, and there are also other background similarities. This organization often uses the word family ties or unity, or Parsadaan Marga Dohot Anak Bruna. The unity organizations hold recitation meetings as well as a social gathering. There are meetings once a month, and there are also meetings once in two months. One of this unity organization's goals is to establish kinship, friendship, and discuss kinship development that lifts the economy, health, and others. Members must build a sense of unity as implied in Mandailing and Angkola community expressions, "Manyuruk Rap Unduk, Mangalumpat Rap Gas" (harmonize together on all matters). Thus, caring for mutual assistance values between one another is taught in the culture of Mandailing and Angkola. Dalihan Na Tolu community always prioritizes the principles of deliberation, brotherhood, friendship, and harmony in all areas of life. The strong sense of kinship and brotherhood in the Dalihan Na Tolu community makes one factor that creates brotherhood and intimacy, including in every tradition, Islamic holidays, and events of a state agenda as regional head elections. Disputes occur between two or more people, even though they are different villages, different support, different parties, and others will usually be quickly resolved due to the familial relationship between them according to Dalihan $\mathrm{Na}$ Tolu concept. As for the tools to reduce disputes in the Dalihan Na Tolu indigenous people are (1) Religion, (2) Clan, (3) Kinship Speech, and (4) Marriage. The Dalihan $\mathrm{Na}$ Tolu indigenous people have the following principles of life: Marsihaholongan (loving each other), Marsipagodakkon (raising/lifting each other), Marsihapadean (doing good with one another), Marsibegean (listen to each other), Marsipagabean (give each other joy), Marsipangiboan (give mercy), Marsitolongan (help each other), Marsilehenan (give each other), Marsihargaan (mutual respect), and Marsipaingotan (remind each other).

With Dalihan Na Tolu, a family democracy in Mandailing and Angkola communities emerged and took root. This familial democracy fostered by consensus agreement. The essence of the consensus agreement results is: (1) Individual opinions are not accepted; general opinions are decisive. (2) Do not take it in mind. It is good to take it out. (3) The majority is happy if no minority complains. (4) Expected decisions, i.e., decisions that can be accepted by everyone. (5) A sense of humanity that is just and civilized is very dependent on the community.

One form of effort made by Mandailing tribe to preserve local culture is by strengthening the local identity of Mandailing community, strengthening the role of the customary leader, strengthening the synergy between traditional government and government (Effendi, 2018). The study results by Sinaga (2012) stated the central role of traditional leaders, teachers, writers, and religious leaders in strengthening character education in the Batak tribe. The role played by

Copyright ( $(2020$. Owned by Author(s), published by Society. This is an open-access article under the CC-BY-NC-SA license. https://doi.org/10.33019/society.v8i2.212

623 
parents is also very decisive for character building for children. The results of research by Lubis (2019) stated that parents in instilling adolescent morals have played their role, such as providing motivation, provide guidance, and help their children to have good moral values. Parents' obstacles in instilling adolescent morals are parents 'busy earning a living and adolescents who do not listen to their parents' advice or guidance.

\section{Conclusion}

Generally, Mandailing and Angkola tribes' characters building through 1) Socialization, including education, clarification, and motivation. 2) Enculturation, including imitation, habituation, and evaluation. 3) Internalization. There are several shapes of Islamic character in Mandailing and Angkola communities in Medan City: religious, independent, wander, critical, dare to uphold the truth, great sense of shame (parsulaha), adaptable, and high sense of kinship. Character education was built by the Mandailing and Angkola tribes through culture and traditional customs based on Islamic religious values to foster self-awareness, foster concern for culture and traditions, and preserve local wisdom to maintain from generation to generation. Also, several efforts to preserve culture by collaborating with schools and traditional and religious leaders combine local wisdom and culture into schools' curriculum and extracurricular activities.

\section{Acknowledgment}

The author is grateful to express gratitude to those who have had the pleasure to work during this research, especially to the traditional leaders of Mandailing and Angkola tribes in North Sumatra Province who have given their time and provided much information on socialcultural values, character, and much more.

\section{Declaration of Conflicting Interests}

The author has declared no potential conflicts of interest concerning the research, authorship, and/or publication of this article.

\section{References}

An-Nahlawi, A. (1995). Pendidikan Islam di rumah, sekolah, dan masyarakat. (E. Erinawati, Ed.). Jakarta, Indonesia: Gema Insani Press.

Andiarini, S. E., Arifin, I., \& Nurabadi, A. (2018). Implementasi Program Penguatan Pendidikan Karakter Melalui Kegiatan Pembiasaan Dalam Peningkatan Mutu Sekolah. Jurnal Administrasi Dan Manajemen Pendidikan, 1(2), 238-244. https://doi.org/10.17977/um027v1i22018p238

Asmani, J. M. (2012). Buku Paduan Internalisasi Pendidikan Karakter di Sekolah. Yogyakarta, Indonesia: Diva Press.

Asrori, M., \& Ali, M. (2011). Psikologi Remaja. Jakarta, Indonesia: PT Bumi Aksara.

Asyarafah, A. (2011). Pendidikan Karakter: Nilai Inti Bagi Upaya Pembinaan Kepribadian Bangsa. Yogyakarta, Indonesia: Widya Aksara Press.

Berger, P. L., \& Luckmann, T. (1990). Social Construction of Reality, Treaties of Sociologi of Knowledge. New York: Penguin Books.

Demetrovics, Z. (2012). Adolescent Behavior and Health in Cross-Cultural Context. The Journal of Early Adolescence, 32(1), 14-19. https:/ / doi.org/10.1177/0272431611432713 
Effendi, H. (2018). Rekonstruksi Fungsi Bagas Godang Dan Sopo Godang Sebagai Culture Heritage Di Tanah Mandailing. Jurnal Education and Development, 6(2), 25-30. Retrieved from http://journal.ipts.ac.id/index.php/ED/article/view/682

Emilda, N. (2018). Nilai Karakter dalam Habituasi Budaya Masyarakat Kampung Adat Cireundeu. Jurnal RUPA, 3(1), 55-61. https:// doi.org/10.25124/rupa.v3i1.1241

Febriansyah, Y. W. (2017). Enkulturasi Pendidikan Karakter Pada Nilai Adat Pikukuh Tilu Dalam Kehidupan Sosial Budaya Masyarakat Sunda Wiwitan Cigugur: Studi Etnografi Pada Penganut Kepercayaan Sunda Wiwitan Kampung Wage Kelurahan Cigugur Kabupaten Kuningan (Master's dissertation). Universitas Pendidikan Indonesia. Retrieved from http://repository.upi.edu/id/eprint/32604

Fitriyani, A., Suryadi, K., \& Syam, S. (2015). Peran Keluarga Dalam Mengembangkan Nilai Budaya Sunda. SOSIETAS, 5(2). https:// doi.org/10.17509/sosietas.v5i2.1521

Frye, M. (2002). Character Education: Informational Handbook and Guide for Support and Implementation of the Student Citizent Act of 2001. North Carolina: Public Schools of North Carolina.

Goleman, D. (2007). Emotional Intelligence. Jakarta, Indonesia: PT Gramedia Pustaka Utama. Hasanah, A. (2012). Pendidikan Karakter Berspektif Islam. Bandung, Indonesia: Insan Komunika.

Hasanah, A., Gustini, N., \& Rohaniawati, D. (2016). Cultivating Character Education Based On Sundanese Culture Local Wisdom. Jurnal Pendidikan Islam, 2(2), 231-253. https://doi.org/10.15575/jpi.v2i2.788

Hidayat, R., \& Rafida, T. (2019). Islamic Character Education Values In Mandailing And Angkola Communities In North Sumatera Province. IJLRES, 3(1), 149-165. http://jurnal.uinsu.ac.id/index.php/ijlres/article/view/4159

Hidayat, R., Hasballah, Z., \& Alfiansyah Siregar, F. (2020). Construction of Islamic Character Education in Deli Malay Culture in Medan City. Dharmawangsa: International Journal of the Social Sciences, Education and Humanities, 1(2), 42-57. https://doi.org/10.46576/english.v1i2.614

Jeynes, W. H. (2017). A Meta-Analysis on the Relationship Between Character Education and Student Achievement and Behavioral Outcomes. Education and Urban Society, 51(1), 3371. https://doi.org/10.1177/0013124517747681

Koentjaraningrat. (2009). Pengantar Ilmu Antropologi. Jakarta, Indonesia: PT Rineka Cipta.

Koesoema, D. A. (2011). Pendidikan Karakter: Strategi Mendidik Anak di Zaman Global. Jakarta, Indonesia: Grasindo.

Lickona, T. (1991). Educating for Character: How Our School Can Teach Respect and Responsibility. New York, London, Sydney, Aucland: Bantam Books.

Lubis, M. J. (2019). Peran orangtua dalam menanamkan akidah akhlak remaja di Desa Muara Batang Angkola Kecamatan Siabu Kabupaten Mandailing Natal (Thesis). IAIN Padangsidimpuan. Retrieved from http:/ / etd.iain-padangsidimpuan.ac.id/3009/

Manda, D., \& Babo, R. (2016). Penyimpangan Sosial Human Trafficking. Equilibrium: Jurnal Pendidikan, 4(1), 30-37. https:/ / doi.org/10.26618/equilibrium.v4i1.484

Ngangi, C. R. (2011). Konstruksi Sosial dalam Realitas Sosial. AGRI-SOSIOEKONOMI, 7(2), 1-4. https:/ / doi.org/10.35791/agrsosek.7.2.2011.85

Pattaro, C. (2016). Character education: Themes and researches. An academic literature review. Italian Journal of Sociology of Education, 8(1), 6-30. http://dx.doi.org/10.14658/pupj-ijse2016-1-2

Polomo, M. (2004). Sosiologi Kontemporer. Jakarta, Indonesia: Rajawali Pers. 
Pradana, M. R. (2016). Imitasi Budaya Hip Hop Amerika Serikat Di Kalimantan Timur. eJournal Ilmu Hubungan Internasional, 4(4), 1223-1238. https://ejournal.hi.fisipunmul.ac.id/site/wp-content/uploads/2017/08/eJournal (08-31-17-01-02-33).pdf

Prayoga, R. (2017). Village Expansion and Its Implication towards Socio-Cultural Life of the Society: (A Study at 'Kundi Bersatu' Society Simpang Teritip Sub-District West Bangka Regency). Society, 5(2), 84-99. https://doi.org/10.33019/society.v5i2.56

Pulungan, D. Z. (2017). Budaya 'Marsialap Ari' Refleksi Pembentukan Karakter Masyarakat Mandailing. Seminar Nasional Pendidikan Bahasa Indonesia. Penguatan Pendidikan Karakter Melalui Pembelajaran Bahasa dan Sastra Indonesia, 348-354. Palembang, Indonesia. Retrieved from http://conference.unsri.ac.id/index.php/SNBI/article/view/530

Ratih, D. (2019). Nilai-Nilai Kearifan Lokal dalam Tradisi Misalin di Kecamatan Cimaragas Kabupaten Ciamis. ISTORIA: Jurnal Pendidikan Dan Ilmu Sejarah, 15(1), 45-57. https://doi.org/10.21831/istoria.v15i1.24184

Saihu, S., \& Mailana, A. (2019). Teori pendidikan behavioristik pembentukan karakter masyarakat muslim dalam tradisi Ngejot di Bali. Ta'dibuna: Jurnal Pendidikan Islam, 8(2), 163. https://doi.org/10.32832/tadibuna.v8i2.2233

Sinaga, A. (2012). Peran Sastra Etnis Batak Dalam Mengembangkan Pendidikan Karakter. Jurnal Pendidikan Bahasa Dan Sastra, 2(1), 15-30. Retrieved from https://onlinejournal.unja.ac.id/pena/article/view/1439

Siregar, M. A. S. (2020). Ziarah Kubur, Marpangir, Mangan Fajar: Tradisi Masyarakat Angkola dan Mandailing Menyambut Bulan Ramadhan dan 'Idul Fitri. Warisan, 1(1), 9-13. Retrieved from https://www.mahesainstitute.web.id/ojs2/index.php/warisan/article/view/164

Siswoyo. (2005). Metode Pengembangan Moral Anak Prasekolah. Yogyakarta, Indonesia: Fakultas Ilmu Pendidikan Universitas Negeri Yogyakarta.

Sugiyono. (2016). Metode Penelilitian Kuantitatif dan Kualitatif dan RED. Bandung, Indonesia: Alfabeta.

Soekanto, S. (2012). Sosiologi: Suatu Pengantar. Jakarta: PT Raja Grafindo Persada.

Suyitno, I. (2012). Pengembangan Pendidikan Karakter Dan Budaya Bangsa Berwawasan Kearifan Lokal. Jurnal Pendidikan Karakter, 2(1), 1-13. Retrieved from https://journal.uny.ac.id/index.php/jpka/article/view/1307

Ufie, A. (2016). Mengonstruksi Nilai-Nilai Kearifan Lokal (Local Wisdom) Dalam Pembelajaran Muatan Lokal Sebagai Upaya Memperkokoh Kohesi Sosial (Studi Deskriptif Budaya Niolilieta Masyarakat Adat Pulau Wetang Kabupaten Maluku Barat Daya, Propinsi Maluku). Jurnal Pendidikan Dan Pembelajaran (JPP), 23(2), 79-89. Retrieved from http://journal.um.ac.id/index.php/pendidikan-dan-pembelajaran/article/view/10157 Ulwan, A. N. (2013). Pedoman Pendidikan Anak dalam Islam. Semarang, Indonesia: CV Asy Syifa. Walker, D. I., Roberts, M. P., \& Kristjánsson, K. (2015). Towards a new era of character education in theory and in practice. Educational Review, 67(1), 79-96. https://doi.org/10.1080/00131911.2013.827631

Yuniati, A., Suyahmo, S., \& Juhadi, J. (2017). Perilaku Menyimpang dan Tindak Kekerasan Siswa SMP di Kota Pekalongan. Journal of Educational Social Studies, 6(1), 1-6. Retrieved from https://journal.unnes.ac.id/sju/index.php/jess/article/view/16249 


\section{About the Author}

Rahmat Hidayat, obtained his Doctoral degree in Islamic Education from Universitas Islam Negeri Sunan Gunung Djati, in 2016. The author is an Assistant Professor at the Department of Islamic Education, Faculty of Islamic Studies, Universitas Dharmawangsa, Indonesia.

E-Mail: rahmathidayat@dharmawangsa.ac.id 